\title{
ШЛЯХИ ПІДВИЩЕННЯ ЕФЕКТИВНОСТІ ЛІКУВАННЯ ТА ПРОФІЛАКТИКИ РЕПЕРФУЗІЙНОГО СИНДРОМУ У ХВОРИХ НА ГОСТРИЙ КОРОНАРНИЙ СИНДРОМ (ІНФАРКТ МІОКАРДА), ЯКИМ ПРОВЕДЕНО БАЛОННУ АНГІОПЛАСТИКУ TA СТЕНТУВАННЯ КОРОНАРНОÏ АРТЕРIÏ
}

\author{
๑М. І. Швед, Л. В. Цуглевич, С. М. Геряк, Н. М. Ковбаса, \\ О. О. Прокопович, І. О. Ястремська
}

ДВНЗ «Тернопільський державний медичний університет імені І. Я. Горбачевського МОЗ України»

РЕзЮмЕ. В Україні відзначено зростання захворюваності на інфаркт міокарда серед осіб працездатного віку (48,9 на 100 тис.), а ішемічна хвороба серця посідає перше місце серед причин первинного виходу на інвалідність (22,8 \%). 3 огляду на вищенаведені факти, пріоритетними $€$ розробка та вдосконалення методів лікування хворих на гострий коронарний синдром (інфаркт міокарда) (ГКС (ІМ)).

Мета - підвищити ефективність лікування та профілактики реперфузійного синдрому у хворих на ГКС (IM), яким проведено коронарне стентування, шляхом включення в терапію L-аргініну та L-карнітину (тіворелю).

Матеріал і методи. Обстежено 45 хворих на гострий коронарний синдром з елевацією сегмента ST, яким було проведено ургентну балонну ангіопластику та стентування інфарктзалежної коронарної артерії. Вік пацієнтів - від 43 до 75 років, у середньому $(59,57 \pm 8,07)$ року. Серед них переважали чоловіки $(82,2$ \%). Дослідну групу склали 30 пацієнтів, які отримували стандартне протокольне лікування ГКС (IM) і яким додатково призначали 4,2 г L-аргініну та 2,0 г L-карнітину (препарат «Тіворель», Юрія-Фарм, Україна) у формі розчину для інфузій по 100 мл один раз на добу курсом 5 днів внутрішньовенно. До контрольної групи увійшли 15 пацієнтів із ГКС (IM), яким також проведено ургентну балонну ангіопластику та стентування інфарктзалежної коронарної артерії, але хворі цієї групи отримували тільки стандартне протокольне лікування.

Результати. Встановлено, що у хворих на ГКС (IM) після перкутанного коронарного втручання найчастіше розвивався реперфузійний синдром із проявами лівошлуночкової недостатності та порушень ритму. Під впливом стандартного медикаментозного лікування у хворих контрольної групи відмічено суттєве клініко-функціональне покращення, але прогресувало післяінфарктне ремоделювання з порушенням систолічної та діастолічної функцій серця, з розвитком синдрому серцевої недостатності та ендотеліальної дисфункції судин, а також зберігалась резистентна до лікування екстрасистолія.

У хворих на ГКС (IM) дослідної групи під впливом комплексного медикаментозного лікування із включенням L-аргініну та L-карнітину відмічено достовірне зменшення частоти порушень ритму і провідності вже на другу добу спостереження, а також зменшення проявів постінфарктного ремоделювання лШ, що в кінцевому результаті проявлялося достовірним покращенням скоротливості міокарда (ФВ зросла на 13 \%) та зменшенням діастолічної дисфункції.

Висновок. Покращення інотропної функції серця та достовірне зниження частоти і вираження реперфузійних аритмій досягнуто за рахунок кардіометаболічного впливу L-карнітину, а відновлення ендотеліальної функції судин наставало завдяки терапевтичному впливу L-аргініну.

КЛючОВІ СЛОВА: гострий коронарний синдром; перкутанне коронарне втручання; реперфузійний синдром; L-аргінін; L-карнітин.

Вступ. В Україні спостерігається зростання захворюваності на інфаркт міокарда серед осіб працездатного віку (48,9 на 100 тис.), а ішемічна хвороба серця продовжує посідати перше місце серед причин первинного виходу на інвалідність (22,8 \%) [4]. Вищенаведені факти визначають пріоритетність розробки і вдосконалення методів лікування хворих на гострий коронарний синдром (інфаркт міокарда) (ГКС (IM)) [2, 7, 8].

Безпосередньою причиною розвитку ГКС (IM) вважають розрив атероматозної бляшки і утворення в коронарній артерії тромбу, який і викликає прогресуючий стеноз. Втім, останнім часом обговорюється ключова роль і таких патогенетичних чинників, як дисліпідемія, системне низькоінтенсивне запалення, пероксидний стрес і порушення ендотеліальної функції, які лежать в основі порушення енергетичного метаболізму та ішемічного пошкодження кардіоміоцитів. Вказаний патогенетичний механізм розвитку ГКС (IM) передбачає можливість медикаментозного впливу на ці патологічні процеси метаболічної та цитопротекторної терапії.

Найбільш перспективними і фізіологічними метаболічними препаратами виявились L-карнітин та L-аргінін. L-аргінін володіє антигіпоксичною, мембраностабілізувальною, антиоксидантною та дезінтоксикаційною активністю, проявляє себе як активний регулятор проміжного обміну і процесів енергозабезпечення $[6,14]$, але основна його фі- 
Огляди літератури, оригінальні дослідження, погляд на проблему, ювілеї

зіологічна роль - це регуляція функціонального стану судин і забезпечення відповідного рівня мікроциркуляції органів і тканин організму $[11,13]$. L-карнітин відіграє важливу роль в енергетичному обміні в міокарді за рахунок переносу вільних жирних кислот з цитозолю всередину мітохондрій, забезпечуючи біодоступність високоенергетичного субстрату для окисного метаболізму в кардіоміоциті $[9,16]$, що позитивно впливає на метаболізм і функцію лівого шлуночка $[10,12,17,18]$.

Наведені вище факти стали обґрунтуванням для дослідження клінічної ефективності та можливості корекції метаболічних порушень у хворих на ГКС (IM).

Мета дослідження - підвищити ефективність лікування та профілактики реперфузійного синдрому у хворих на ГКС (IM), яким проведено коронарне стентування, шляхом включення в терапію L-аргініну та L-карнітину (тіворелю).

Матеріал і методи. Обстежено 45 хворих на гострий коронарний синдром з елевацією сегмента ST, яким було проведено ургентну балонну ангіопластику та стентування інфарктзалежної коронарної артерії і які перебували на лікуванні у кардіологічному відділенні Тернопільської університетської лікарні в 2018 році. У дослідження відібрано хворих у віці від 43 до 75 років, в середньому $(59,57 \pm 8,07)$ року. Серед досліджуваного контингенту переважали чоловіки (82,2 \%). Діагноз верифікували відповідно до рекомендацій ESC [15] при наявності типового ангінозного нападу, динаміки специфічних змін кривої електрокардіограми (реципрокне зміщення сегмента ST) та ознак некрорезорбтивного синдрому.

Дослідну групу склали 30 пацієнтів, які отримували стандартне протокольне лікування ГКС (IM) і яким додатково призначали 4,2 г L-аргініну та 2,0 г L-карнітину (препарат «Тіворель», Юрія-Фарм, Україна) у формі розчину для інфузій по 100 мл один раз на добу курсом 5 днів внутрішньовенно. До контрольної групи увійшли 15 пацієнтів з ГКС (IM), яким також проведено ургентну балонну ангіопластику та стентування інфарктзалежної коронарної артерії, але хворі цієї групи отримували лише стандартне протокольне лікування.

Окрім загальноклінічних, інструментальних та лабораторних методів (загальний аналіз крові, MB фракції креатинфосфокінази (КФК-МВ), тропоніну Т, насичення артеріальної крові киснем $\left(\mathrm{SpO}_{2}\right)$, ЕКГ у 12 стандартних відведеннях тощо), проводили ехокардіографію у В-режимі апаратом Aloka SSD-2000 (США) із визначенням лінійних та об'ємних показників лівого шлуночка, а також глобальної (за фракцією викиду, ФВ) та локальної скорочувальної активності міокарда за методом Simpson. Діастолічну функцію лівого шлуночка оцінювали за часом ізоволюмічного розслаблення лівого шлуночка (IVRT), часом сповільнення швидкості раннього наповнення лівого шлуночка (DT), максимальною швидкістю раннього його наповнення (E) та максимальною швидкістю наповнення лівого шлуночка у період систоли передсердь (А) [1].

Функціональний стан судинного ендотелію визначали за концентрацією ендотеліну-1(ЕT-1) у плазмі крові (за допомогою імуноферментного набору фірми «Amersham Pharmacia Biotech») та вмістом стабільних метаболітів NO, які визначали за реакцією з реактивом Гріса [5]. Розрахунок кількості нітритів здійснювали за калібрувальним графіком.

Статистичну обробку отриманих результатів виконували за допомогою пакета статистичних програм Statistica 10.0 та програми Microsoft Exel2013. Для оцінки даних використовували непараметричні методи статистики - Манна-Уїтні U-тест для порівняння показників у двох групах (p<0,05).

Результати й обговорення. Серед обстежуваних ГКС (IM) у чоловіків зустрічався у 4,6 раза частіше, ніж у жінок, що порівнянно з даними літератури. у більшості випадків ГКС розвинувся на фоні артеріальної гіпертензії - 27 (60,0 \%) осіб. У 38 (84,4 \%) хворих мала місце дис- або гіперхолестерине-

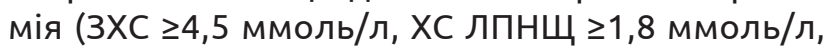
Т 22,0 ммоль/л). У 31 (68,4 \%) хворого простежувалось поєднання цих двох факторів ризику IXC. Серед інших несприятливих чинників у досліджуваних відмічали надлишкову масу тіла - у 14 (31,1 \%), цукровий діабет 2 типу - у 12 (26,7 \%), куріння - у 28 хворих, що склало 62,2 \% усіх досліджуваних. Серед жінок переважали особи старшої (7 хворих) вікової категорії, у всіх 9 жінок настала менопауза.

Клінічна картина ГКС (IM) у більшості обстежених хворих проявлялась класичним ангінозним болем, характерними змінами електрокардіографічної кривої та некрорезорбтивним синдромом. Участини пацієнтів $(11,1 \%)$ діагностували атиповий клінічний початок інфаркту міокарда.

Порушення ритму і провідності серця діагностували у 93 (65 \%) обстежених хворих, найчастіше реєстрували шлуночкові або суправентрикулярні екстрасистоли (у 78,5 \%), пароксизми фібриляції передсердь (у 11,8 \%), шлуночкову тахікардію (у 5,4 \%), блокади різного ступеня та локалізації (у $45,1 \%)$.

Всім пацієнтам для верифікації діагнозу проводили морфофункціональне дослідження серця і контрастну коронароангіографію з наступною ангіопластикою та стентуванням інфарктзалежної коронарної артерії (в середньому через $(6,28 \pm 1,43)$ год після появи ангінозного нападу). За результатами проведеної ургентної коронаро- 
Огляди літератури, оригінальні дослідження, погляд на проблему, ювілеї

ангіографії (КАГ) було встановлено заключний діагноз для кожного хворого. При цьому можна констатувати, що кількість та анатомічне вираження ураження коронарних артерій суттєво не відрізнялися між хворими вказаних груп.

Аналізуючи структуру та частоту розвитку ускладнень в обстежених групах хворих, виявлено, що розвиток гострої аневризми передньої стінки лівого шлуночка (33,3 проти 0,0\%, $\mathrm{p}=0,017)$ та тромбендокардиту у верхівці лівого шлуночка (26,7 проти 0,0\%, p=0,037) достовірно частіше спостерігали у хворих, яким проводили протокольне медикаментозне та кардіореабілітаційне лікування. Разом з тим, у пацієнтів дослідної групи, яким у комплексне медикаментозне лікування додатково призначали курс терапії L-аргініном та L-карнітином, вказані ускладнення не виникали взагалі. Більше того, в обстежених хворих обох груп, яким вчасно (в межах 2-12 год від початку ангінозного нападу) провели ургентну ангіопластику та стентування інфарктзалежної коронарної артерії, такі ускладнення, як рання післяінфарктна стенокардія, кардіогенний шок, набряк легень, механічні (розрив вільної стінки лівого шлуночка, міжшлуночкової перегородки, відрив сосочкових м'язів), взагалі не зафіксовано. Водночас зауважимо, що у хворих на ГКС (IM) у післяопераційному періоді (після перкутанного коронарного втручання, ПКВ) найчастіше розвивався реперфузійний синдром із різною тривалістю та вираженням лівошлуночкової недостатності і порушень ритму та провідності (рис. 1). Як видно з представлених даних, у вихідному стані безпосередньо після проведеної ПКВ у хворих на ГКС (IM) обох груп реєстрували однакову частоту та види порушень ритму і провідності $(p>0,05)$.

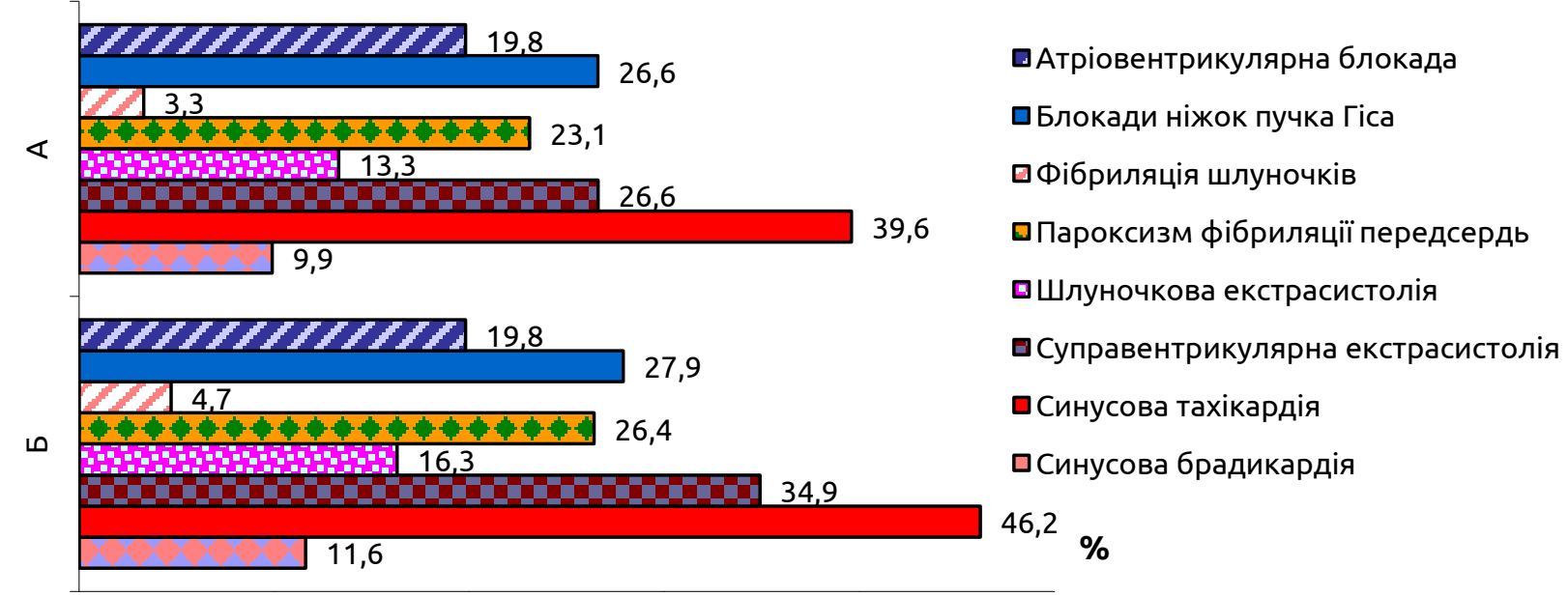

Рис. 1. Частота розвитку порушень ритму та провідності у хворих на ГКС (ІМ) дослідної (А) і контрольної (Б) груп.

Під впливом стандартного медикаментозного та відновного лікування відмічено суттєве зменшення частоти порушень ритму і провідності у хворих контрольної групи вже на другу добу спостереження. Резистентними до такого лікування залишались суправентрикулярні та шлуночкові екстрасистоли. Більше того, вказані аритмії залишались і наприкінці другого тижня лікування, що обґрунтовувало застосування додаткової антиаритмічної терапії.

У хворих на ГКС (IМ) дослідної групи під впливом комплексного медикаментозного лікування із включенням L-аргініну та L-карнітину також відмічено суттєве зменшення частоти порушень ритму $\mathrm{i}$ провідності вже на другу добу спостереження, але у пацієнтів цієї групи достовірно вищими залишались частота синусової тахікардії та суправентрикулярної екстрасистолії. Такий результат можна пояснити додатковим зниженням систолічного i діастолічного артеріального тиску внаслідок покращення мікроциркуляції під впливом L-аргініну. По завершенні курсу запропонованого комплексного лікування (8-10 доба) частота порушень ритму і провідності у хворих дослідної групи достовірно знижувалась і була достовірно нижчою порівняно з показниками групи порівняння $(p<0,05)$.

Результати ехокардіографічного дослідження (табл. 1) засвідчують, що у вихідному стані у хворих на ГКС (IМ) дослідної та контрольної груп вони статистично не відрізняються, але суттєво відрізняються від аналогічних у здорових людей (референтні значення). При цьому зауважимо, що у вихідному стані у хворих на ГКС (IM) діагностували систолічну та діастолічну дисфункцію ЛШ, про що засвідчують збільшення показників КСОлш, КДОлш, A, IVRT, DT та зниження ФВ, Е, Е/А. Скоротлива функція лівого шлуночка внаслідок розвитку ГКС (IM) знижувалась у середньому на $22 \%$. 
Огляди літератури, оригінальні дослідження, погляд на проблему, ювілеї

Таблиця 1. Динаміка гемодинамічних показників під впливом комплексної терапії із включенням L-аргініну

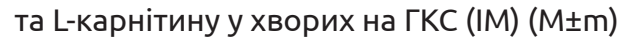

\begin{tabular}{|c|c|c|c|c|c|c|c|}
\hline \multicolumn{2}{|c|}{$\begin{array}{c}\text { Показники та їх референтні } \\
\text { значення }\end{array}$} & \multirow{2}{*}{$\begin{array}{c}1 \text { доба } \\
151,5 \pm 1,2\end{array}$} & \multirow{2}{*}{$\begin{array}{c}10 \text { доба } \\
146,3 \pm 1,4 \\
\end{array}$} & \multirow{2}{*}{$\frac{28 \text { доба }}{144,4 \pm 1,4}$} & \multirow{2}{*}{$\begin{array}{c}\mathrm{p} 1 \\
<0,05 \\
\end{array}$} & \multirow{2}{*}{$\begin{array}{c}\text { p2 } \\
<0,05 \\
\end{array}$} & \multirow{2}{*}{$\begin{array}{c}\mathrm{p} 3 \\
<0,05 \\
\end{array}$} \\
\hline КДОлш, мл & 1 & & & & & & \\
\hline$(156,4 \pm 1,4)$ & 2 & $152,1 \pm 1,4$ & $158,8 \pm 1,6$ & $159,2 \pm 1,6$ & $<0,05$ & $<0,05$ & $<0,05$ \\
\hline \multirow{2}{*}{$\begin{array}{l}\text { КСОлш, мл } \\
(81,3 \pm 3,8)\end{array}$} & 1 & $88,6 \pm 2,7$ & $86,5 \pm 3,2$ & $81,3 \pm 2,8$ & $>0,05$ & $>0,05$ & $<0,05$ \\
\hline & 2 & $89,3 \pm 2,3$ & $89,4 \pm 2,5$ & $93,9 \pm 2,3$ & $>0,05$ & $>0,05$ & $>0,05$ \\
\hline \multirow{2}{*}{$\begin{array}{l}\text { ФВ, \% } \\
(59,8 \pm 0,3)\end{array}$} & 1 & $46,9 \pm 0,4$ & $51,2 \pm 0,2$ & $53,8 \pm 0,23$ & $<0,05$ & $>0,05$ & $<0,05$ \\
\hline & 2 & $47,9 \pm 0,4$ & $46,5 \pm 0,3$ & $48,6 \pm 0,6$ & $>0,05$ & $>0,05$ & $>0,05$ \\
\hline \multirow{2}{*}{$\begin{array}{l}\text { IVRT, MC } \\
(88,5 \pm 2,1)\end{array}$} & 1 & $82,6 \pm 1,3$ & $76,3 \pm 1,3$ & $68,1 \pm 2,1$ & $<0,05$ & $<0,05$ & $<0,05$ \\
\hline & 2 & $83,7 \pm 2,1$ & $78,4 \pm 1,5$ & $74,3 \pm 2,1$ & $>0,05$ & $>0,05$ & $<0,05$ \\
\hline \multirow{2}{*}{$\begin{array}{l}\text { DT, MC } \\
(196,4 \pm 4,7)\end{array}$} & 1 & $169,9 \pm 5,3$ & $185,4 \pm 5,2$ & $234,4 \pm 4,8$ & $<0,05$ & $<0,05$ & $<0,05$ \\
\hline & 2 & $179,5 \pm 4,4$ & $186,6 \pm 4,6$ & $194,6 \pm 4,5$ & $>0,05$ & $>0,05$ & $>0,05$ \\
\hline \multirow{2}{*}{$\begin{array}{l}\mathrm{E}, \mathrm{cm} / \mathrm{c} \\
(45,67 \pm 1,7)\end{array}$} & 1 & $61,5 \pm 1,8$ & $63,2 \pm 1,8$ & $65,61 \pm 1,6$ & $>0,05$ & $>0,05$ & $<0,05$ \\
\hline & 2 & $62,2 \pm 1,3$ & $53,2 \pm 1,3$ & $48,7 \pm 1,4$ & $<0,05$ & $>0,05$ & $<0,05$ \\
\hline \multirow{2}{*}{$\begin{array}{l}\text { A, cM/c } \\
(36,8 \pm 1,1)\end{array}$} & 1 & $44,3 \pm 1,3$ & $37,2 \pm 1,2$ & $32,8 \pm 1,1$ & $<0,05$ & $<0,05$ & $<0,05$ \\
\hline & 2 & $42,7 \pm 1,1$ & $48,5 \pm 1,2$ & $54,8 \pm 1,1$ & $<0,05$ & $<0,05$ & $<0,05$ \\
\hline \multirow{2}{*}{$\begin{array}{l}\mathrm{E} / \mathrm{A} \\
(1,23 \pm 0,04)\end{array}$} & 1 & $1,36 \pm 0,04$ & $1,43 \pm 0,04$ & $1,03 \pm 0,04$ & $>0,05$ & $<0,05$ & $<0,05$ \\
\hline & 2 & $1,44 \pm 0,05$ & $1,35 \pm 0,06$ & $1,19 \pm 0,05$ & $>0,05$ & $>0,05$ & $<0,05$ \\
\hline
\end{tabular}

Примітка. 1,2 - відповідно, показники у хворих на ГКС (ІМ) дослідної (n=30) та контрольної (n=15) груп; р1, р2, р3 - відповідно, достовірність різниці між параметрами у хворих на ГКС (IM) у 1 та 10 день лікування, у 10 і 28 день та між хворими у 1 і 28 день.

Під впливом проведеної стандартної терапії до 10 доби у хворих на ГКС (IM) суттєво зростали показники КДОлш, IVRT, DT, А та, відповідно, знижувалися такі показники інтракардіальної гемодинаміки, як E, E/A, ФВ. Таким чином, на 10 добу IM у хворих контрольної групи на фоні медикаментозного та відновного лікування за стандартною схемою мало місце ремоделювання серця із поступовим збільшенням об'ємів його камер та зниженням скоротливої здатності. Одночасно у хворих розвивалася діастолічна дисфункція переважно за релаксаційним типом. Після одномісячного курсу стандартного лікування у хворих даної групи спостерігали продовження постінфарктного ремоделювання ЛШ, що проявлялось достовірним збільшенням КДОлш, IVRT, DT та зменшенням E, E/A. ФВ дещо зростала до 28 дня проведеної терапії (на 1,5-4,3 \%) порівняно з показником на 1-10 добу стандартного лікування $(p<0,05)$. Проте цей показник після завершення лікування був достовірно нижчий, ніж у здорових осіб. Отримані дані свідчать про недостатню гемодинамічну ефективність стандартної терапії у цієї групи хворих.

У хворих на ГКС (IM) дослідної групи, яким до стандартної терапії додавали курс лікування L-apгініном та L-карнітином, при повторному обстеженні (на 10 добу) відмічено достовірне збільшення DT та ФВ і зменшення КДОлш та коефіцієнта E/A, зміни решти показників гемодинаміки були несуттєвими порівняно з вихідними даними, проте відмічалась тенденція до зменшення постін- фарктного ремоделювання серця. Одночасно відмічено розвиток діастолічної дисфункції за релаксаційним типом. Так, на 28 добу застосованої терапії достовірно зростав показник IVRT та ФВ і зменшувалися $\mathrm{E}, \mathrm{A}, \mathrm{E} / \mathrm{A}$ порівняно з вихідним значенням. Таким чином, додавання до стандартного медикаментозного та відновного лікування у цих пацієнтів L-аргініну та L-карнітину сприяло зменшенню розмірів лівих камер серця, проявів постінфарктного ремоделювання ЛШ, що в кінцевому результаті проявлялося достовірним зростанням ФВ (у середньому на $13 \%$ ), скоротливості міокарда та зменшенням діастолічної дисфункції.

У процесі дослідження вивчали також зміни показників ендотеліальної функції судин у хворих на ГКС (IM) і було встановлено, що у вихідному стані вони не відрізнялись між собою, але були суттєво порушені порівняно з референтними. Так, при госпіталізації рівень ендотеліну-1 в плазмі крові у хворих на ГКС (IM) був в 2,1 раза вищий від референтної норми (відповідно $(0,96 \pm 0,04)$ та $(0,46 \pm$ $0,03)$ нг/мл) і його активність суттєво не змінювалася безпосередньо після ургентної ангіопластики коронарної судини та її стентування. Разом з тим, у пацієнтів контрольної групи, яким проводили протокольне медикаментозне та відновне лікування, рівень ендотеліну суттєво знижувався, але і в кінці стаціонарного етапу лікування не досягав рівня здорових осіб $(0,66 \pm 0,06 ;$ р>0,05).

На відміну від цього, у хворих дослідної групи, яким у комплексне лікування додатково 
Огляди літератури, оригінальні дослідження, погляд на проблему, ювілеї

включали курс терапії L-аргініном та L-карнітином, в наступні 10 діб стаціонарного етапу лікування активність ЕТ-1 знижувалась на 33,3 \% (p<0,05), а після одномісячного лікування його активність у плазмі крові достовірно знижувалась ще на 43 \% і досягала рівня здорових осіб $((0,52 \pm 0,05)$ нг/мл; p>0,05). Тобто, застосування комплексної медикаментозної терапії з включенням L-аргініну та L-карнітину на фоні індивідуалізованої програми кардіореабілітації у хворих на ГКС (IM) сприяло швидкому зниженню (протягом 10 діб) і повному відновленню (протягом 28 діб) активності ендотеліну-1 у плазмі крові цих пацієнтів.

Одночасно зі змінами активності ендотеліну-1 у хворих на ГКС (IM) в період загострення хвороби наставало різке зниження рівня метаболітів оксиду азоту $(\mathrm{NO} \varepsilon=(17,75 \pm 0,42)$ мкмоль/л при нормі $(36,92 \pm 0,37)$ мкмоль/л), що могло свідчити про виражене порушення мікроциркуляції у цих пацієнтів. Так, концентрація нітратів та нітритів у вихідному стані у хворих обох груп знижувалась майже в 2,0 рази, а загальний їх вміст у плазмі крові падав на 45,0 \%. При цьому зауважимо, що загальновживане протокольне лікування не забезпечувало повного відновлення ендотеліальної функції судин у цієї групи пацієнтів із ГКС (IM), загальна концентрація метаболітів оксиду азоту у плазмі крові у них була на 19 \% нижчою від референтного показника $(p<0,05)$. Водночас застосування комплексної медикаментозної терапії із включенням L-apгініну та L-карнітину у пацієнтів дослідної групи суттєво впливало на концентрацію нітритів та нітратів у плазмі крові, їх рівень достовірно зростав уже до 10 доби лікування і по завершенні стаціонарного етапу комплексного медикаментозного та відновного кардіореабілітаційного лікування досягав референтної норми.

Таким чином, отримані результати комплексного дослідження клініко-функціонального стану хворих на ГКС (IM) дозволяють зробити висновок, що у хворих на ГКС (IM) в післяопераційному періоді (після перкутанного коронарного втручання) часто розвивався реперфузійний синдром із різною тривалістю та вираженням лівошлуночкової недостатності, порушень ритму і провідності. Під впливом стандартного медикаментозного та відновного лікування у хворих контрольної групи відмічено суттєве зменшення частоти порушень ритму і провідності вже на другу добу спостереження, але резистентними до такого лікування залишались суправентрикулярні та шлуночкові екстрасистоли, що обґрунтовувало застосування додаткової антиаритмічної терапії. Втім, у хворих на ГКС (IM) дослідної групи під впливом комплексного медикаментозного лікування із включенням L-аргініну та L-карнітину на фоні індивіду- алізованої програми кардіореабілітації вже на другу добу спостереження відмічено суттєве зменшення частоти порушень ритму і провідності, але достовірно вищими залишались частота синусової тахікардії та суправентрикулярної екстрасистолії, що можна було пояснити компенсаторною реакцією на додаткове зниження систолічного і діастолічного артеріального тиску під впливом запропонованого лікування.

Діагностика у вихідному стані у хворих на ГКС (IM) виражених порушень морфофункціональних параметрів серця, післяінфарктного ремоделювання з порушенням систолічної та діастолічної функцій серця, з розвитком синдрому серцевої недостатності та ендотеліальної дисфункції судин, які зберігались безпосередньо після ургентного перкутанного втручання, стали обґрунтуванням для включення в склад протокольної програми терапії курсу парентерального застосування L-аргініну та L-карнітину. Було встановлено недостатню гемодинамічну ефективність стандартної терапії у цієї групи хворих і лише додавання до стандартної терапії L-аргініну та L-карнітину приводило до достовірного збільшення ФВ, DT і зменшення КДОлш, коефіцієнта Е/А та до зменшення постінфарктного ремоделювання серця, що в кінцевому результаті проявлялося достовірним зростанням ФВ, скоротливості міокарда та зменшенням діастолічної дисфункції. Отриманий позитивний результат впливу запропонованого лікування на інотропну функцію серця та достовірне зниження частоти і вираження реперфузійних аритмій, на нашу думку, досягнуто саме за рахунок кардіометаболічного впливу L-карнітину, який, за даними багатьох дослідників, відіграє важливу роль в енергетичному обміні в міокарді за рахунок переносу вільних жирних кислот з цитозолю всередину мітохондрій і тим самим забезпечує біодоступність високоенергетичного субстрату для окисного метаболізму в кардіоміоциті $[10,12]$. Крім того, полегшуючи оксидацію довголанцюгових жирних кислот та модулюючи співвідношення КоА до КоA-SH, сполука бере участь у зв'язуванні ацильних залишків у пероксисомах і мітохондріях та позитивно впливає на обмін амінокислот, асимілюючи масив вільнорадикальних сполук, що забезпечує стабілізацію органел і клітинних мембран та попереджує накопичення в цитоплазмі кардіоміоцитів ефірів жирних кислот, які можуть приводити до виникнення фатальних шлуночкових аритмій [16-18]. у процесі дослідження було також встановлено, що у хворих дослідної групи, яким в комплексне лікування додатково включали курс терапії L-аргініном та L-карнітином на фоні індивідуально адаптованої програми кардіореабілітації, після 10-денного лікування активність ЕT-1 достовірно знижувалась, а 
Огляди літератури, оригінальні дослідження, погляд на проблему, ювілеї концентрація метаболітів оксиду азоту в плазмі крові підвищувалась, досягаючи рівня здорових осі6 (p>0,05). Тобто, таке комплексне лікування у хворих на ГКС (IM) сприяло швидкому і повному відновленню досліджуваних показників ендотеліальної функції судин. Отриманий результат лікування можна пояснити застосуванням L-аргініну як основного субстрату для синтезу оксиду азоту. В багатьох дослідженнях було продемонстровано, що застосування L-аргініну після проведення стентування зменшувало число рестенозів [3, 6, 14] завдяки його антигіпоксичній, антиоксидантній та мембраностабілізувальній активності, але основна його фізіологічна роль - це регуляція функціонального стану судин і забезпечення відповідного рівня мікроциркуляції органів і тканин організму $[11,13,16]$.

У цілому завдяки комплексному застосуванню комбінованої медикаментозної терапії із Включенням L-аргініну та L-карнітину (тіворелю) на фоні індивідуалізованої програми кардіореабілітації досягнуто достовірного покращення параметрів центральної кардіогемодинаміки та відновлення ендотеліальної функції судин, що супроводжувалось суттєвим зменшенням частоти розвитку та вираження таких ускладнень ГКС (IM), як реперфузійні аритмії та гостра серцева (лівошлуночкова) недостатність.

Висновки. 1. У хворих на ГКС (IM) у вихідному стані спостерігаються виражені порушення морфофункціональних параметрів серця, розвиток його післяінфарктного ремоделювання з порушенням систолічної та діастолічної функцій серця та розвитком синдрому серцевої недостатності та ендотеліальної дисфункції судин.

2. Морфофункціональні порушення параметрів серця приводили до розвитку ускладненого перебігу ГКС (IM), в першу добу після перкутанного коронарного втручання на фоні стандартної медикаментозної та відновної терапії найчастіше діагностували реперфузійний синдром із проявами гострої лівошлуночкової недостатності та порушень ритму і провідності.

3. Застосування комплексної медикаментозної терапії із включенням L-аргініну та L-карнітину (тіворелю) на фоні індивідуалізованої програми кардіореабілітації приводило до достовірного покращення параметрів центральної кардіогемодинаміки та відновлення ендотеліальної функції судин, що супроводжувалось суттєвим зменшенням частоти розвитку та вираження таких ускладнень ГКС (IM), як реперфузійні аритмії та гостра лівошлуночкова недостатність.

Перспективи подальших досліджень. Отримано позитивні клінічні результати комбінованої медикаментозної терапії із включенням L-аргініну та L-карнітину (тіворелю) у хворих на ГKC (IM), що проявилось покращенням інотропної функції серця та достовірним зниженням частоти і вираження реперфузійних аритмій, а це обґрунтовує доцільність дослідження патофізіологічних механізмів такого впливу.

\section{ЛІТЕРАТУРА}

1. Абдуллаев Р. Я. Принципы эхокардиографической оценки диастолической функции левого желудочка / Р. Я. Абдуллаев, И. К. Латогуз, М. А. Власенко // Эксперимент. и клин. мед. - 2001. - № 4. - С. 59-62.

2. Уніфікований клінічний протокол екстреної, первинної, вторинної та третинної медичної допомоги «Гострий коронарний синдром з елевацією сегмента ST» // МОЗ України. - 2014. - 78 с.

3. Батушкін В. В. Цитопротекція при гострому інфаркті міокарда після відкриття інфаркт-залежної артерії: нові горизонти / В. В. Батушкін // Ліки України (Medicine of Ukraine). - 2017. - № 8 (214). - C. 33-40.

4. Коваленко В. М. Актуальні проблеми здоров'я та мінімізація їх в умовах збройного конфлікту в Україні : посібник / В. М. Коваленко, В. М. Корнацький. - К. : ННЦ «Інститут кардіології ім. М. Д. Стражеска», 2018. - 215 с.

5. Кондаков І. Л. Способи морфо-функціонального дослідження стану ендотелію : метод. рек. / І. Л. Кондаков, А. Ф. Яковенко. - Харків, 2000. - 18 с.

6. Вибір оптимальної комбінації метаболічних препаратів для лікування пацієнтів із кардіоваскулярною патологією / М. М. Селюк, М.М.Козачок, І.М.Льовкін, О. В. Селюк // Семейная медицина. - 2017. - № 2 (70). С. 60-64.

7. Швед М. І. Сучасні технології відновного лікування хворих із гострим коронарним синдромом / М. І. Швед, Л. В. Левицька. - К. : Видавн. дім «Медкнига», 2018. $176 \mathrm{c}$.

8. Реабілітація хворих на інфаркт міокарда та гострий коронарний синдром після перкутанного коронарного втручання : метод. рек. / М. І. Швед, Л. В. Левицька, А. І. Кланца, Л. В. Цуглевич. - Хмельницький, 2018. -40 c.

9. Astashkin E. I. Role of L-carnitine in energy metabolism cardiomyocytes and treatment of diseases of cardiovascular system / E. I. Astashkin, M. G. Glezer // Cardiology and Cardiovascular Surgery. - 2012. - Vol. 6 (2). - P. 58-65.

10. L-carnitine in the secondary prevention of cardiovascular disease: Systematic review and meta-analysis / J. DiNicolantonio, C. Lavie, H. Fares [et al.] // Mayo Foundation for Medical Education and Research Mayo Clin. Proc. 2013. - P. 1-8.

11. Celermajer D. S. Endothelial dysfunction: does it matter? Is it relevant? // J. Am. Coll. Cardiol. - 1997. Vol. 30. - P. 325-333.

12. Colonna P. Myocardial infarction and left ventricular remodeling: results of the CEDIM trial / P. Colonna, S. Iliceto // Am. Heart J. - 2000. - Vol. 139 (2, pt 3). - P. 124-130. 
Огляди літератури, оригінальні дослідження, погляд на проблему, ювілеї

13. Haynts W. G. Endothelin as a regulator of cardiovascular function in health and disease / W. G. Haynts, D. J. Webb // J. of Hypertension. - 2008. - Vol. 16. P. 1081-1098.

14. L-arginine attenuates lymphocyte activation and antioxidized LDL antibody levels in patients undergoing angioplasty / J. George, S. B. Shmuel, A. Roth [et al.] // Atherosclerosis. - 2004. - Vol. 174. - P. 323-327.

15. 2017 ESC Guidelines for the management of acute myocardial infarction in patients presenting with ST-segment elevation: The Task Force for the management of acute myocardial infarction in patients presenting with STsegment elevation / B. Ibanez, S. James S. Agewall [et al.] // Eur. Heart J. - 2018. - Vol. 2. - P. 119-177. Mode access : https://doi.org/10.1093/eurheartj/ehx393.

16. Opie L. H. Role of carnitine in fatti acid metabolism of normal and ischemic myocardium / L. Opie // Am. Heart J. -1997. - Vol. 97 (3). - P. 375-388.

17. High doses of L-carnitine in acute myocardial infarction: metabolic and antiarrhythmic effects / P. Rizzon, G. Biasko, M. Di Biase [et al.] // Eur. Heart J. - 1989. Vol. 10 (6). - P. 502-508.

18. Changes in tissue levels of carnitine and other metabolites during myocardial ischemia and anoxia / A. Shug, J. Thomsen, J. Folts [et al.] // Arch. Biochem. Biophys. 1998. - Vol. 187 (1). - P. 25-33.

\section{REFERENCES}

1. Abdullayev, R.Ya., Latoguz, I.K., \& Vlasenko, M.A. (2001). Printsipy ekhokardiograficheskoy otsenki diastolicheskoy funktsii levogo zheludochka [The principles of echocardiographic evaluation of the diastolic function of the left ventricle]. Eksperimentalnaya i klinicheskaya meditsinaExperimental and Clinical Medicine, 4, 59-62 [in Russian].

2. MOZ Ukrainy (2014). Unifikovanyi klinichnyi protokol ekstrenoi, pervynnoi, vtorynnoi ta tretynnoi medychnoi dopomohy "Hostryi koronarnyi syndrom z elevatsiieiu sehmenta ST" [Ministry of Health of Ukraine. Unified clinical protocol of emergency, primary, secondary and tertiary care "Acute coronary syndrome with elevation of segment ST"]. [in Ukrainian].

3. Batushkin, V.V. (2017). Tsytoprotektsiia pry hostromu infarkti miokarda pislia vidkryttia infarkt-zalezhnoi arterii: novi horyzonty [Cytoprotection in acute myocardial infarction after the discovery of a heart attack-dependent artery: new horizons]. Liky Ukrainy - Medicine of Ukraine, 8 214), 33-40 [in Ukrainian].

4. Kovalenko, V.M., \& Kornatskyi, V.M. (2018). Aktualni problemy zdorovia ta minimizatsiia yikh v umovakh zbroinoho konfliktu v Ukraini (posibnyk) [Actual problems of health and minimization of them in conditions of armed conflict in Ukraine (manual)]. Kyiv: M.D. Strazhesk Institute of Cardiology [in Ukrainian].

5. Kondakov, I.L., \& Yakovenko, A.F. (2000). Sposoby morfo-funktsionalnoho doslidzhennia stanu endoteliiu. Metodychni rekomendatsii [Methods of morpho-functional study of the state of the endothelium. Methodical recommendations]. Kharkiv [in Ukrainian].

6. Seliuk, M.M., Kozachok, M.M., Lovkin, I.M., \& Seliuk, O.V. (2017). Vybir optymalnoi kombinatsii metabolichnykh preparativ dlia likuvannia patsiientiv z kardiovaskuliarnoiu patolohiyeiu [Choice of the optimal combination of metabolic drugs for the treatment of patients with cardiovascular pathology]. Semeynaya meditsyna Family Medicine, 2 (70), 60-64 [in Russian].

7. Shved, M.I., \& Levytska, L.V. (2018). Suchasni tekhnolohii vidnovnoho likuvannia khvorykh iz hostrym koronarnym syndromom [Modern technologies of restorative treatment of patients with acute coronary syndrome]. Kyyiv: Vydavn. dim Medknyha [in Ukrainian].

8. Shved, M.I., Levytska, L.V., Klantsa, A.I., \& Tsuhlevych, L.V. (2018). Reabilitatsiia khvorykh na infarkt miokarda ta hostryi koronarnyi syndrom pislia perkutannoho koro- narnoho vtruchannia (metodychni rekomendatsii) [Rehabilitation of patients with myocardial infarction and acute coronary syndrome after percutaneous coronary intervention (methodical recommendations)]. Khmelnytsk [in Ukrainian].

9. Astashkin, E.I., \& Glezer, M.G. (2012). Role of L-carnitine in energy metabolism cardiomyocytes and treatment of diseases of cardiovascular system. Cardiology and Cardiovascular Surgery, 6 (2), 58-65.

10. DiNicolantonio, J., Lavie, C., \& Fares, H. (2013). L-Carnitine in the secondary prevention of cardiovascular disease: Systematic review and meta-analysis. Mayo Foundation for Medical Education and Research Mayo Clin. Proc., 1-8.

11. Celermajer, D.S. (1997). Endothelial dysfunction: does it matter? Is it relevant? J. Am. Coll. Cardiol, 30, 325333.

12. Colonna, P., \& Iliceto, S. (2000). Myocardial infarction and left ventricular remodeling: results of the CEDIM trial. Am. Heart J., 139 (2, pt 3), 124-130.

13. Haynts, W.G., \& Webb, D.J. (2008). Endothelin as a regulator of cardiovascular function in health and disease. J. of Hypertension, 16, 1081-1098.

14. George, J., Shmuel, S.B., Roth, A., Herz, I., Izraelov, S., Deutsch, V., ... \& Miller, H. (2004). L-arginine attenuates lymphocyte activation and antioxidized LDL antibody levels in patients undergoing angioplasty. Atherosclerosis, 174, 323-327.

15. Ibanez, B., James, S., Agewall, S., Antunes, M.J., Bucciarelli-Ducci, Ch., \& Bueno, H. (2018). 2017 ESC Guidelines for the management of acute myocardial infarction in patients presenting with ST-segment elevation: The Task Force for the management of acute myocardial infarction in patients presenting with ST-segment elevation. Eur. Heart J., 2, 119-177. Retrieved from: https://doi. org/10.1093/eurheartj/ehx393.

16. Opie, L.H. (1997). Role of carnitine in fatty acid metabolism of normal and ischemic myocardium. Am. Heart J., 97 (3), 375-388.

17. Rizzon, P., Biasko, G., \& Di Biase, M. (1989). High doses of L-carnitine in acute myocardial infarction: metabolic and antiarrhythmic effects. Eur. Heart J., 10 (6), 502508.

18. Shug, A., Thomsen, J., \& Folts, J. (1998). Changes in tissue levels of carnitine and other metabolites during myocardial ischemia and anoxia. Arch. Biochem. Biophys, 187 (1), 25-33. 


\title{
ПУТИ ПОВЫШЕНИЯ ЭФФЕКТИВНОСТИ ЛЕЧЕНИЯ И ПРОФИЛАКТИКИ РЕПЕРФУЗИОННОГО СИНДРОМА У БОЛЬНЫХ ОСТРЫМ КОРОНАРНЫМ СИНДРОМОМ (ИНФАРКТОМ МИОКАРДА), КОТОРЫМ ПРОВЕДЕНО БАЛЛОННУЮ АНГИОПЛАСТИКУ И СТЕНТИРОВАНИЕ КОРОНАРНОЙ АРТЕРИИ
}

\author{
๑Н. И. Швед, Л. В. Цуглевич, С. Н. Геряк, Н. М. Ковбаса, \\ А. А. Прокопович, И. А. Ястремская
}

\author{
ГВУз «Тернопольский государственный медицинский университет имени И. Я. Горбачевского \\ МОЗ Украины»
}

РЕЗЮМЕ. В Украине наблюдается рост заболеваемости инфарктом миокарда среди лиц трудоспособного возраста (48,9 на 100 тыс.), а ишемическая болезнь сердца (ИХС) занимает первое место среди причин первичного выхода на инвалидность (22,8 \%). Учитывая приведенные факты, приоритетными являются разработка и совершенствование методов лечения больных острым коронарным синдромом (инфарктом миокарда) (ОКС (ИМ)).

Материал и методы. Обследовано 45 больных острым коронарным синдромом с елевацией сегмента ST, которым было проведено ургентную баллонную ангиопластику и стентирование инфарктзависимой коронарной артерии. Возраст пациентов - от 43 до 75 лет, в среднем $(59,57 \pm 8,07)$ года. Среди них превалировали мужчины (82,2 \%). Опытную группу составили 30 пациентов, которые получали стандартное протокольное лечение OKC (ИМ) и которым дополнительно назначали 4,2 г L-аргинина и 2,0 г L-карнитина (препарат «Тиворель», ЮрияФарм, Украина) в форме раствора для инфузий по 100 мл один раз в сутки курсом 5 дней внутривенно. В контрольную группу вошли 15 пациентов с ОКС (ИМ), которым также проведено ургентную баллонную ангиопластику и стентирование инфарктзависивой коронарной артерии, но больные этой группы получали только стандартное протокольное лечение.

Цель - повысить эффективность лечения и профилактики реперфузионного синдрома после коронарного стентирования у больных ОКС (ИМ) путём включения в терапию L-аргинина и L-карнитина (тивореля).

Результаты. Установлено, что у больных ОКС (ИМ) после перкутанного коронарного вмешательства часто розвивался реперфузионный синдром с проявлениями левожелудочковой недостаточности и нарушений ритма. Под влиянием стандартного медикаментозного лечения у больных контрольной группы отмечено существенное клинико-функциональное улучшение, но прогресировало послеинфарктное ремоделирование с нарушениями систолической и диастолической функции сердца, с развитием синдрома сердечной недостаточности и эндотелиальной сосудистой дисфункции, а также сохранялась резистентная к лечению экстрасистолия.

у больных ОКС (ИМ) опытной группы под влиянием комплексного медикаментозного лечения с включением L-аргинина и L-карнитина отмечено достоверное уменьшение частоты нарушений ритма и проводимости уже на вторые сутки наблюдения, а также уменьшение проявлений постинфарктного ремоделирования лж, что, в конечном результате, проявлялось достоверным улучшением сократимости миокарда (ФВ возросла на 13 \%) и уменьшением диастолической дисфункции.

Вывод. Увеличение инотропной функции сердца и достоверное снижение частоты и выраженности реперфузионных аритмий достигнуто за счет кардиометаболического влияния L-карнитина, а восстановление эндотелиальной сосудистой функции наступало под терапевтическим влиянием L-аргинина.

КЛЮЧЕВЫЕ СЛОВА: острый коронарный синдром; перкутанное коронарное вмешательство; реперфузионный синдром; L-аргинин; L-карнитин.

\section{WAYS FOR IMPROVEMENT OF CENTRAL AND PERIPHERAL HEMODYNAMICS IN PATIENTS WITH ACUTE CORONARY SYNDROME (MYOCARDIAL INFARCTION), WHO UNDERWENT BALLOON ANGIOPLASTY AND STENTING OF THE CORONARY ARTERY}

\author{
@M. I. Shved, L. V. Tsuglevich, S. M. Heryak, N. M. Kovbasa, \\ O. O. Prokopovich, I. O. Jastremska \\ I. Horbachevsky Ternopil State Medical University
}

SUMMARY. In Ukraine, there is an increase in the incidence of myocardial infarction among people of working age (48.9 per 100 thousand), and coronary heart disease (IHD) ranks first among the causes of primary disability (22.8 \%). Considering the above facts, the development and improvement of treatment methods for patients with acute coronary syndrome (myocardial infarction) (ACS) is a priority.

Material and Methods. 45 patients with acute coronary syndrome with ST segment elevation were examined, who underwent urgent balloon angioplasty and stenting of the infarction-dependent coronary artery. The age of patients was from 43 to 75 years, on average $(59.57 \pm 8.07)$ years. Men prevailed among them (82.2 \%). The experimental group consisted of 30 patients who received standard protocol treatment of ACS (MI) and who were additionally prescribed $4.2 \mathrm{~g}$ of L-arginine and $2.0 \mathrm{~g}$ of L-carnitine (Tivorel, Yuriia Farm, Ukraine) in the form of a solution for infusion of $100 \mathrm{ml}$ 
Огляди літератури, оригінальні дослідження, погляд на проблему, ювілеї

once a day course of 5 days intravenously. The control group included 15 patients with ACS (MI), who also underwent urgent balloon angioplasty and stenting of the infarct coronary artery, but patients of this group received only standard protocol treatment.

The aim - to improve the efficiency of treatment and prevention of the reperfusion syndrome in patients with coronary stenting by means of the inclusion of L-arginine and L-carnitine (Tivorel) in therapy patients with acute coronary syndrome (miocardial infarction).

Results and Discussion. It was established that in patients with ACS after percutaneous coronary intervention, reperfusion syndrome with manifestations of left ventricular insufficiency and rhythm disturbances most often developed. Substantial clinical and functional improvement was noted under the influence of standard medical treatment in patients of the control group, but postinfarction remodeling with systolic and diastolic function of the heart, with the development of heart failure syndrome and endothelial dysfunction of blood vessels, and also remained resistant to extrasystole therapy, progressed.

Patients with ACS (MI) of the experimental group under the influence of complex medical treatment with the inclusion of L-arginine and L-carnitine marked a significant decrease in the frequency of violations of rhythm and conduction for the second day of observation, as well as a decrease in the manifestations of post-infarction remodeling of left ventricular, which ultimately manifested itself a significant improvement in myocardial contractility (EF increased by $13 \%$ ) and decreased diastolic dysfunction. Improvement of the inotropic function of the heart and a significant reduction in the frequency and severity of reperfusion arrhythmias were achieved through the cardiometabolic effect of L-carnitine, and restoration of endothelial function of the vessels was induced by the therapeutic effects of L-arginine.

Conclusion. An increase in inotropic cardiac function and a significant reduction in the frequency and severity of reperfusion arrhythmias was achieved due to the cardiometabolic effect of L-carnitine, and the restoration of endothelial vascular function occurred under the therapeutic influence of L-arginine.

KEY WORDS: acute coronary syndrome; percutaneous coronary intervention; reperfusion syndrome; L-arginine; L-carnitine.

Отримано 21.02.2019 